\section{Differences in leaf area, trichome density, and xylem structure between the two types of Theobroma cacao I. cultivation: With or without shade plants}

\author{
Erma Prihastanti, Yulita Nurchayati \\ Department of Biology, Faculty of \\ Science and Mathematics, Diponegoro \\ University, Semarang, Central Java, \\ Indonesia
}

\begin{abstract}
This study aimed to analyze the structure and density of non-glandular trichomes and the area of cocoa leaves, and the differences of xylem vessel structures on various shade tree composition. The leaf area and length, and trichomes were observed. The xylem vessel structure was observed from the root system. The result showed the area of cocoa plots without shade tree has more varied leaves size, in which upper canopy was smaller than the bottom. The area with various shade had a relatively equal size between the upper and the lower of the canopy. The three stellate-shaped non-glandular trichomes were found on the leaf venations only with the density in two plots increased with time. The xylem width area to the whole root width area ratio $(\mathrm{k})$ in various shade trees was lower $(\mathrm{k}=0.641)$ than that of without shade trees $(\mathrm{k}=0.718)$. The higher $\mathrm{k}$ values indicated xylem structure without the shade tree had more xylem cells, and the pores was smaller compared to the plot with various shade trees.
\end{abstract}

\section{Introduction}

Cocoa plants are usually cultivated with other annual ones, causing some differences in the microclimate, such as light or canopy. Each plant has different canopy structures and roots as an adaptation. Canopy structure, plant physiology, leaf area index, and conductance of stomata affect the transpiration. ${ }^{1}$ Unsaturated hydraulic conductivity is a major component in the study of groundwater motion and the transportation of dissolved substances. The presence of vegetation due to the different land use greatly affects the unsaturated hydraulic conductivity. Vegetation is thought to increase the unsaturated hydraulic conductivity caused by soil porosity due to plant rooting. ${ }^{2-4}$

The correlation between the leaf struc- ture and climate has been studied by Rodriguez-Iturbe et al., ${ }^{5}$ where the leaf morphology is closely related to rainfall and temperature. The aspects of functional variation in leaf structure, such as the shape and surface or their combination, often occur intentionally due to the selection of coordination functions or genetic traits associated with their evolution.

Environmental variations affect the structure of adult leaves because the leaves structurally vary with the intensity and quality of the light surrounding them during the development. The specific leaf area is one of the critical properties of plant growth because it can describe the leaf area to light and $\mathrm{CO}_{2}$ in leaf biomass. The leaf area index is the most common measure of canopy development. It is susceptible to water shortages, resulting in a decrease in leaf formation, leaf expansion and aging, and leaf threshing. Leaf expansion is more sensitive to water shortages than to stomatal closure, photosynthesis and leaf aging. ${ }^{6}$

The aspects of the functional variation of the leaf structure, such as the shape and surface or their combination, often occur due to the adaptive mechanisms to the growing environment. One form of anatomical and physiological changes can be observed from the changes in the trichome structure and leaf area. The trichomes of leaves are classified as glandular and nonglandular. ${ }^{7}$ Cocoa plants have stellate type non-glandular trichomes. ${ }^{6}$ Non-glandular trichome acts as physical protection of plants against biotic and abiotic stresses, forms a mechanical barrier to low humidity and high light intensity and temperature, prevents water loss, and protects plant organs from insect damage. ${ }^{8,9}$

The density of the leaf trichome varies and is determined by genetic and environmental factors. The development of leaf trichomes often begins in the early stages of leaf development, sometimes also before the leaf primordium can be distinguished. In some plants, trichomes can be determined during leaf differentiation or when new trichomes are formed at all stages of leaf development. ${ }^{9}$

The availability of water in plants is determined through physiological processes, and the loss of water from the surface of the plants is determined through evaporation and transpiration. ${ }^{10}$ The root is a vital plant organ that absorbs water and nutrients from the soil. The developed rooting systems effectively absorb water and nutrients and rapidly transport the material to the canopy. ${ }^{11,12}$ The movement of the water from the ground to the leaves through the roots and stems is caused by the potential difference of the water between the soil and
Erma Prihastanti, Department of Biology, Faculty of Science and Mathematics, Diponegoro University, Semarang, Central Java, Indonesia.

Tel.: 0247474754 .

E-mail: eprihast@yahoo.co.id.

Key words: Trichomes; leaf area; xylem structure; shade tree; Theobroma cacao L.

Contributions: EP: Conception and design, analysis and interpretation of data, drafting and revising the article. YN: Analysis and interpretation of data and drafting the article.

Conflict of interest: The authors declare there is no conflict of interest.

Acknowledgements: Authors would like to thank the Directorate of Research and Community Service, the Directorate of General Research and Development, The Ministry of Research, Technology and Higher Education, due to the funding of Fundamental Research from 2015-2016 on this project.

Funding: This research was funded by Fundamental Research from 2015-2016 No: $183-14 / \mathrm{UN} 7.5 .1 / \mathrm{PG} / 2014$ and 18134/UN7.5.1/PG/2016, from Directorate of Research and Community Service, the Directorate of General Research and Development, The Ministry of Research, Technology and Higher Education.

Received for publication: 20 July 2020 .

Revision received: 10 October 2020.

Accepted for publication: 10 October 2020 .

This work is licensed under a Creative Commons Attribution-NonCommercial 4.0 International License (CC BY-NC 4.0).

${ }^{C}$ Copyright: the Author(s), 2020

Licensee PAGEPress srl, Italy

International Journal of Plant Biology 2020; 11:8790 doi:10.4081/pb.2020.8790

plants. ${ }^{10,13}$ The negative pressure causes the water to rise through the xylem, which acts as a very delicate capillary axis. Water molecules attach to cellulose microfibrils and other hydrophilic components of the wall. ${ }^{13,14}$

Xylem provides a low-resistance path for long-range water movement by minimizing the pressure gradient required to transport water from the soil to the leaf. The simplest representation is that xylem is often modeled as a collection of "pipe units," and the water flow is generally approximated by the Hagen-Poiseuille equation. ${ }^{12}$ The pipeline model has contributed to the estimation of canopy-level parameters by combining variations in channel size and amounts at tissue and organ levels and is also used to understand 
tree growth, resource allocation, and plant biomechanics. ${ }^{15}$ In-plant physiology, the theory of Cohesion-Tension Theory (CTT) represents the same conceptual breakthrough. ${ }^{12}$ The xylem structure may change a form of plant adaptation to the changes in the environmental conditions, for example, increasing the thickness of xylem to increase the absorption of water from the soil. ${ }^{16}$ In dried on plants there may be anatomic and physiological changes in the root. The findings of Vasellati et al. ${ }^{17}$ revealed that the inundated state of Australian grass plants (Paspalum dilalatum) would increase the formation of aerenchyma in the cortex part of the roots. In contrast, the drought condition would decrease the diameter of the root metaxylem. The thickening of the cortex size in a drought state is an adaptation of the plant to improve water-use efficiency. Joseph et al. ${ }^{18}$ suggest that parenchymal tissue in drought-dense plants will increase in thickness and have enlarged cell size. Cell size enlargement improves waterway and water-use efficiency. This study aimed to analyze the structure and density of nonglandular trichomes and the area of cocoa leaves and to analyze the differences between the structures of the xylem vessel, such as the ratio of the area and the diameter of xylem root holes of cocoa plants on various shade tree compositions.

\section{Materials and Methods}

\section{Plant materials and treatments}

The cocoa trees used in this study were around 7-8 years old and were of heterogeneous varieties (hybrid and local varieties). From each tree, two leaves at the bottom (shady leaves) and two leaves that were exposed to the sun (sun leaves) were taken to analyze trichome and leaf area. Moreover, from each tree, three pieces of root system with a diameter of $3-5 \mathrm{~mm}$ at a depth of $20 \mathrm{~cm}$ were taken to observe the xylem vessel structure. Cocoa root samples were used for permanent preparations.

\section{Experiment location and research plot}

The research was conducted at a cocoa plantation in Plana Village, District of Somagede, Banyumas Regency, Central Java Province, Indonesia, from December 2014 to August 2016 and included site surveys, plot determination, sampling, and variable measurements. The cocoa field area that was used is owned by the farmers who started planting cocoa trees in 2008 . The varieties used were heterogeneous (hybrid and local varieties) and obtained from Lampung Province, Indonesia. In the research, two plots $\left(2500 \mathrm{~m}^{2}\right.$ in wide) were planted with cocoa. There were 12 cacaos in each plot, in the plot I, cocoa was planted without the presence of a shade tree, whereas in plot II, cocoa was planted with the presence of shade trees, such as albasia, gliricidia, cocos, Bangladesh tree, and duku. Based on the geographical area, the research site was located $96 \mathrm{~m}$ above sea level, with the amount of rainfall being 200-300mm per year and the average air humidity ranging from 47 to $80 \%$. The average air temperature above the tree canopy was $30.4{ }^{\circ} \mathrm{C}$, whereas, under the tree canopy, it was $29.7^{\circ} \mathrm{C}$. The occurrence of rainfall from December 2014 to August 2016 indicates a spreading of rainfall (200300 per year).

\section{Anatomical characteristic}

The canopy areas were measured using the leaf area index. The trichome density was measured by counting the amount of leaf trichome, whereas the xylem root diameter was measured in micrometers using photomicrographs.

\section{Statistical analysis}

The data were analyzed using t-test and analysis of variance (ANOVA), followed by Duncan's multiple range test (DMRT) show significant differences.

\section{Results}

\section{Leaf area of cocoa tress on the upper and lower canopy}

The leaf area of cocoa trees between upper and lower canopy showed no signifi- cant difference $(p>0.05)$. Our study also showed that the leaf area of cocoa tress in the upper canopy with no shade tree was smaller than that with various shade trees, 204.30 and $214.66 \mathrm{~cm}^{2}$, respectively. In other hands, the leaf area of cocoa tress under lower canopy with no shade tree was bigger than that with various shade trees, 234.61 and $220.19 \mathrm{~cm}^{2}$, respectively.

\section{The tricomes structure and density of cocoa leaves cultivated with or without a shade tree}

The trichomes of cocoa leaves in all planting plots were of stellate (star) shape and showed found on the leaf venation. The non-glandular trichomes of cacao showed stellate shape and multicellular, have four to eight branches, and sessile or stalked (Figure 1). The shading condition showed significantly effect $(\mathrm{p}<0.05)$ on the nonglandular tricomes number of cocoa leaves.

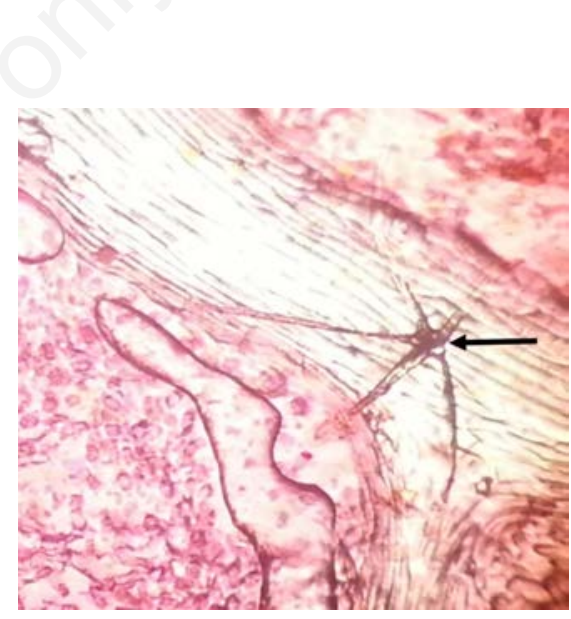

Figure 1. Cocoa trichome on the lower leaf surface $(M=400 \times)$. Black arrow indicates stellate trichome.

Table 1. Cocoa leaf area in plot I (no shade tree) and plot II (with various shade tree).

\begin{tabular}{lcc} 
Plot & Upper canopy $\left(\mathrm{cm}^{2}\right)$ & Lower canopy $\left(\mathrm{cm}^{2}\right)$ \\
Plot I (No shade tree) & 204.30 & 234.61 \\
Plot II (With various shade trees) & 214.66 & 220.19 \\
\hline
\end{tabular}

Means followed by different letters in each column were significantly different at p-value $\leq 0.05$ based on DMRT test.

Table 2. The density of trichomes of cocoa leaves under upper and low canopy in plot I (no shade tree) and plot II (with various shade tree).

\begin{tabular}{lcc} 
Plot & \multicolumn{2}{c}{$\begin{array}{l}\text { Trichomes number/cm }{ }^{2} \\
\text { August } 2016\end{array}$} \\
The upper canopy & & \\
Plot I (No shade tree) & $52.75^{\mathrm{a}}$ & $66.33^{\mathrm{a}}$ \\
Plot II (With various shade trees) & $14.50^{\mathrm{b}}$ & $44.66^{\mathrm{a}}$ \\
The lower canopy & & \\
Plot I (No shade tree) & $32.50^{\mathrm{a}}$ & $73.33^{\mathrm{a}}$ \\
Plot II (With various shade trees) & $21.50^{\mathrm{b}}$ & $21.00^{\mathrm{b}}$ \\
\hline
\end{tabular}

Means followed by different letters in each column were significantly different at $p$-value $\leq 0.05$ based on DMRT test. 
Both in the upper canopy and lower canopy conditions, the cocoa leaves in the no shade tree area had higher number of non-glandular trichomes than those area with various shade trees (Tables 1 and 2).

\section{Root anatomical structure of cocoa cultivated with or without shade trees}

The cocoa root in the area with no shade tree showed higher $k$ value than that in the plot with various shade trees, 0.718 and 0.641 , respectively (Table 3 and Figure 2). The comparison of the xylem size with a diameter of $\leq 35 \mu \mathrm{m}$ in the plot I (no shade tree) show more number than the cocoa root xylem in plot II (with various shade tree), and the xylem of cocoa root in plot II (with various shade tree) has the high number on the diameter ranged of $35-70 \mu \mathrm{m}$ and $>70$ $\mu \mathrm{m}$ than in plot I (no shade tree) (Table 4). These root profiles indicated that cocoa without shade tree had smaller xylem size than with various shade trees (Table 4).

\section{Discussion}

\section{Leaf area of cocoa trees on the upper and lower canopy}

Shading conditions in cocoa tree plantation showed different in leaf area profile as presented in our study (Table 1). These profiles suggested due to the difference of light exposure between upper and canopy areas. Cocoa tree in the lower canopy got more sunlight exposure than that of upper canopy. Under the low-light condition, the leaf will adapt by enlarging the leaf area to absorb more light. ${ }^{19}$ Shaded Solanum melongena plant had more leaf area compared to unshaded plants, showing acclimation to low light conditions. ${ }^{20}$

The area of the cocoa leaves grown in the plot with various shade trees was larger than that of cocoa leaves in the plot without a shade tree (Table 1). Shade, in coffee plant can trigger some differences in plant physiology, such as an increase in photosynthesis and leaf area index (LAI), resulting in better performance of plants under shade trees than those exposed to direct sunlight.$^{21}$

\section{The trichome structure and density of cocoa leaves cultivated with or without a shade tree}

The trichome structure of cocoa leaves in our study showed similar profile with previous study (Table 2). The trichomes of stellate and sessile are abundant on abaxial surfaces in all three Theobroma species native to the Brazilian Amazon, whereas stellate trichomes are exclusively found on the leaf venation. ${ }^{22}$ In no shading tree area, cocoa leaves showed higher number of trichomes that that of shading tree area (Table 2), this is also reported on Wigandia urens exposed to sun (no shade) had the higher number of trichome than those of plants in shaded areas. ${ }^{23}$ Plants grown in different ecological regions may have different responses to the adaptation to the environment, such as the increase or decrease in trichome formation. ${ }^{24}$ The plot with shade trees of different species, such as albasia, gliricidia, cocos, Bangladesh tree, and duku had a lower temperature $\left(29.5^{\circ} \mathrm{C}\right)$ than that without a shade tree $\left(31^{\circ} \mathrm{C}\right)$. The shade tree can protect the plants from excessive sunlight and high temperatures. In turn, the deciduous leaves will protect the soil from excessive temperatures and will maintain soil moisture. ${ }^{25}$ Plants that tolerate well the shade tree, when exposed under a canopy, will experience reduced stomata and trichomatic density. ${ }^{26}$

\section{Root anatomy of cocoa cultivated with or without shade trees}

The anatomical structures as evidences of the differences in cocoa aging patterns of 7-8

Table 3. Comparison of xylem width area to root width area ratio $(\mathbf{k})$ of cocoa cultivated in plot I (no shade tree) and plot II (with various shade tree).

\begin{tabular}{lc} 
Plot & $\mathrm{k}$ (xylem width area/root width area) \\
Plot I (No shade tree) & 0.718 \\
Plot II (With various shade trees) & 0.641 \\
\hline Means followed by different letters in each column were significantly different at p-value $\leq 0.05$ based on DMRT test.
\end{tabular}

Means followed by different letters in each column were significantly different at p-value $\leq 0.05$ based on DMRT test.

Table 4. Comparison of the number of cocoa root xylem in plot I (no shade tree) and plot II (with various shade tree) based on xylem diameter.

\begin{tabular}{|c|c|c|c|}
\hline Plot & Diameter $\leq 35 \mu \mathrm{m}$ & $\begin{array}{c}\text { Number of xylem } \\
35<\text { Diameter } \leq 70 \mu \mathrm{m}\end{array}$ & Diameter $>70$ \\
\hline Plot I (No shade tree) & 2451.5 & 21 & 4 \\
\hline Plot II (With various shade trees & 2312.7 & 25.2 & 6.6 \\
\hline
\end{tabular}
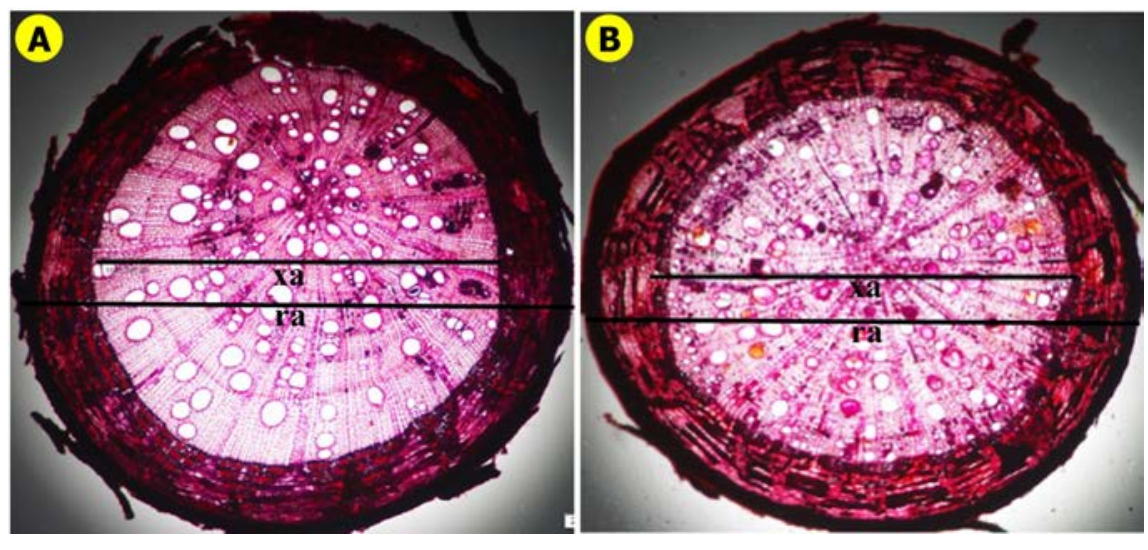

Figure 2. Xylem tissue in the cocoa root stele on the plot without shade tree (A) and various shade trees (B). xa: xylem; ra: root area years in the area with no shade tree and area with various shade trees as presented in our xylem width area to root width area $(k)$ (Table 3 ). A higher $k$ value indicated that cocoa roots ore xylem cells. Cocoa in area without than cocoa in the area with various shade trees. The air temperature below the poly-patcocoa plants have much smaller xylem, which is considered a form of adaptation. Research conducted by Ibrahim et al. ${ }^{27}$ stated that the tracheal diameter but have small numbers. In contrast, tolerant Acacia species have smaller diameters but more numbers. diameter is caused by the decrease in trachea numbers found in Anarthrophyllumchilense, It can help the process of soil. Due to water shortage, the condition of xylem diameter becomes smaller and more size is more useful because it is more resistant adaptation of plants to drought and to keep the balance of the water content in the plant to drought. The anatomical structure is the 
body. ${ }^{29}$ The xylem structure with a small pore size is only able to supply a small amount of water. It seems that this was a cocoa plant responses to adapt in the area with no shade tree, whereas the soil surface has a higher temperature than the cocoa root in a plot with various shade tree. The narrow xylem channel at the roots forces the plant to utilize groundwater more slowly and increase the hydraulic resistance. ${ }^{30,31}$

Research conducted by Carla et al. ${ }^{32}$ stated that under the water pressure, plants could affect the xylem anatomy by increasing the proportion of trachea that can play a role in maintaining hydraulic conductivity. The changes in xylem pore size are one form of anatomical adaptation of plants experiencing drought pressure. According to Fitria and Maryani, ${ }^{29}$ the xylem structure with a small pore size would be more useful because it is more resistant to drought than the xylem with large pore size.

\section{Conclusions}

The area of cocoa leaf in the plot with no shade tree more varied in size. The leaves under the upper canopy are smaller than those at the bottom. In contrast, the extension of cocoa leaves in the plot with various shade trees has a relatively equal size between the upper and the lower leaves of the canopy. The non-glandular trichomes of cocoa leaves with three stellate or star-shaped trichomes can only be found on leaf venations. The density of non-glandular trichomes in the two plots increased in number with time, with a higher increase in plots with relatively lower shade trees ranging from $0.7 \%$ to $29.0 \%$. The ratio of xylem area to the whole root area (k) in the root of the cocoa plant in the plot with various shade trees is lower $(\mathrm{k}=0.641)$ than the cocoa root in a plot $\mathrm{I}(\mathrm{k}=0.718)$. Higher $\mathrm{k}$ values indicate that the root xylem structure of cocoa in the plot with no shade tree has more xylem cells, and the xylem pore is smaller than the root of a cocoa plant in the plot with various shade trees.

\section{References}

1. David M, Peter F, Mark D, Jim W. Measurements of transpiration in four tropical rainforest types of north Queensland, Australia. Hydrol Proc Int J 2007;21:3549-64.

2. Behzad G, Allen GH. Unsaturated hydraulic conductivity in porous media: Percolation theory. Geoderma 2012;187:77-84.

3. Xiao YL, Sergio C, Albert SB. Unsaturated hydraulic conductivity in limestone dolines: Influence of vegetation and rock fragments. Geoderma 2008;45:288-94.

4. Wei H, Shao M, Wang QJ, Jingchao F, Robert H. Temporal changes of soil hydraulic properties under different land uses. Geoderma 2009;149:355-66.

5. Rodriguez-Iturbe I, Porporato A, Laio F, Ridolfi L. Plants in water-controlled ecosystems: Active role in hydrologic processes and response to water stress: I. Scope and general outline. Adv Water Res 2001;24:695-705.

6. Erma P, Soekisman T, Didie S, Ibnul Q. Perubahan struktur dan kepadatan trikomata non glanduler serta luas daun kakao (Theobroma cacao L.) pada perlakuan stress kekurangan air. J Sains dan Mat 2009; 17:18-23.

7. Xinbin D, Guodong W, Dong SY, et al. TrichOME: a comparative omics database for plant trichome. Plant Physiol 2010;152: 44-54.

8. Luiz RST, Stefany CMS, Tatiane MR. Non-glandular trichomes in Lamiaceae and Verbenaceae species: Morphological and histochemical features indicate more than physical protection. New Zealand J Bot 2016;54: 446-57.

9. Walker AR, Marks MD. Trichome initiation in Arabidopsis. Adv Botan Res 2000;31:219-36.

10. Steudle E. The cohesion-tension mechanism and the acquisition of water by plant roots. Annu Rev Plant Biol 2001;52:84775.

11. Bagniewska-Zadworna A, Byczyk J, Eissenstat DM, et al. Avoiding transport bottlenecks in an expanding root system: xylem vessel development in fibrous and pioneer roots under field conditions. Am J Bot 2012;99:1417-26.

12. Hae KK, Joonghyuk P, Ildoo H. Investigating water transport through the xylem network in vascular plants. J Exp Bot 2014;65:1895-1904

13. Melvin TT. Plant hydraulics: The ascent of water. Nature 2003;423:923.

14. Oda Y, Hasezawa S. Cytoskeletal organization during xylem cell differentiation. $\mathrm{J}$ Plant Res 2006;119:167-77.

15. Karl JN, Hanns CS, Julian FVV. Plant biomechanics: An overview and prospectus. Am J Bot 2006;93:1369-78.

16. Xiaopeng L, Yupeng L, Zhong Z, Xingpang L. Influences of environmental factors on leaf morphology of Chinese jujubes. PloS One 2015;10:e0127825.

17. Vasellati V, Oesterheld M, Medan D, Loreti J. Effects of flooding and drought on the anatomy of Paspalum dilatatum. Anna Bot 2001;88:355-60.

18. Joseph GC, Kathleen MB, Jonathan PL. Large root cortical cell size improves drought tolerance in maize. Plant Physiol 2014;166:2166-78.

19. Daniel MJ, William KS, Thomas CV, Craig RB. Leaf architecture and direction of incident light influence mesophyll fluorescence profiles. Am J Bot 2005;92:1425-31.

20. Rosati A, Badeck FW, Dejong TM. Estimating canopy light interception and absorption using leaf mass per unit leaf area in Solanum melongena. Ann Botany 2001;88:101-9.

21. Adugna D, Paul CS. Effects of shade on growth, production and quality of coffee (Coffea arabica) in Ethiopia. J Hort Forest 2011;3:336-41

22. Tarcymara G, Raimunda CVP, Tatiani YSK, et al. Leaf anatomical features of three Theobroma species (Malvaceae s.1.) native to the Brazilian Amazon. Acta Amazonic 2014;44:291-300.

23. Pérez-Estrada LB, Cano-Santana Z, Oyama K. Variation in leaf trichomes of Wigandia urens: environmental factors and physiological consequences. Tree Physiol 2000;20:629-32.

24. Kaizhuan X, Xiaohui M, Yuelong L. Trichome, a functional diversity phenotype in plant. Mol Biol 2017;6:183.

25. Molla MA. Effect of tree shade on coffee crop production. J Sustain Dev 2015;8:66.

26. Gregoriou K, Pontikis K, Stavros NV. Effects of reduced irradiance on leaf morphology, photosynthetic capacity, and fruit yield in olive (Olea europaea L.). Photosynthetica 2007;45:172-81.

27. Ibrahim MA, Abdallah IA, Pervaiz RK, et al. Drought-induced adaptive changes in the seedling anatomy of Acacia ehrenbergiana and Acacia tortilis subsp. Raddiana. Trees 2013;27:959-71.

28. Martin D, Pablo HM, Roberto JF. Xylem efficiency vs. safety: Acclimation to drought of seedling root anatomy for six Patagonian shrub species. J Arid Env 2011;75:397-402.

29. Fitria RR, Maryani M. Root anatomy and growth of Capsicum frutescens L. on verticulture with different watering supply. J Trop Biodiv Biotech 2017;2:1-9.

30. Passioura JB. Environmental biology and crop improvement. Funct Plant Biol 2002;29:537-46.

31. Richard AR. Physiological traits used in the breeding of new cultivars for waterscarce environments. Agr Wat Manage 2006;80:197-211.

32. Carla GR, Molina RV, Teresa PD, Ana MRM, Adrian RB, Ana F. Xylem anatomical study in diverse Capsicum sp. accessions, implication to drought tolerance. Bull Univ Agr Sci Vet Med Cluj-Napoca. Hort 2014;71:256-60. 